Article

\title{
Evaluating Institutional Dichotomy between Urban and Rural Land Administration in Amhara Region, Ethiopia
}

\author{
Worku Nega $^{1, * \mathbb{C}}$, Mulugeta Tenaw ${ }^{1} \mathbb{C}$, Yeneneh Hunie ${ }^{1} \mathbb{D}$, Sayeh Kassaw Agegnehu ${ }^{1}$ and \\ Reinfried Mansberger ${ }^{2}$ (D) \\ 1 Institute of Land Administration, Debre Markos University, Debre Markos 269, Ethiopia; \\ mulugeta_tenaw@dmu.edu.et (M.T.); yeneneh_hunie@dmu.edu.et (Y.H.); sayeh_kassaw@dmu.edu.et (S.K.A.) \\ 2 Institute of Geomatics, University of Natural Resources and Life Sciences, A-1190 Vienna, Austria; \\ mansberger@boku.ac.at \\ * Correspondence: worku_nega@dmu.edu.et
}

Citation: Nega, W.; Tenaw, M.;

Hunie, Y.; Agegnehu, S.K.;

Mansberger, R. Evaluating

Institutional Dichotomy between

Urban and Rural Land

Administration in Amhara Region,

Ethiopia. Sustainability 2021, 13, 9431.

https://doi.org/10.3390/su13169431

Academic Editor: Maria Rosa Trovato

Received: 20 July 2021

Accepted: 13 August 2021

Published: 23 August 2021

Publisher's Note: MDPI stays neutral with regard to jurisdictional claims in published maps and institutional affiliations.

Copyright: (c) 2021 by the authors. Licensee MDPI, Basel, Switzerland. This article is an open access article distributed under the terms and conditions of the Creative Commons Attribution (CC BY) license (https:// creativecommons.org/licenses/by/ $4.0 /)$

\begin{abstract}
Institutional setup in the land administration system plays a crucial role in the successful functioning of modern land administration. The institutional setup, whether separated for urban and rural land administration or unified, is responsible for implementing the legal and policy framework. In most regions of Ethiopia, including the Amhara National Regional State, the institutional setup is separated, which results in increasing difficulties to administer land efficiently. The purpose of this study was to assess the challenges and opportunities of the institutional dichotomy between urban and rural land administration in the Amhara region. Primary and secondary data were used in the study. Questionnaires, focus group discussions (FGDs) and interviews with key informants were applied to collect the data. As the findings of the study revealed, about $55 \%$ of the respondents agreed that the integration between urban and rural land administration institutions is weak. In addition, $38 \%$ of the respondents also confirmed that the integration between the two independent institutions is very weak. The institutional separation between urban and rural land has opened the door for land invasion and informal settlement in peri-urban areas. The study also identifies overlapping job titles, wastage of human and material resources, and promulgation of contradicting urban and rural land laws as the challenges in the region due to the dichotomy of land administration between urban and rural. Although administering urban and rural land in separate institutions helps for minimizing the workload, the findings tend to administer land in a unified institution and within an independent ministry.
\end{abstract}

Keywords: institutional separation; institutional structure; land administration institutions; strength; weakness; unified institution

\section{Introduction}

Traditionally, land administration institutions were established to compile land records that could be used to collect land taxes [1]. One key factor for the effectiveness of a land administration system (LAS) is the institutional setting of land [2,3]. Institutions of land administration play a crucial role in putting the legal and policy framework into action $[2,4]$. Institutional frameworks are not static since they change through time to better facilitate the implementation of LAS and good governance $[2,5]$. The institutional frameworks of land administration differ between countries around the world and often reflect local, cultural and judicial settings [6-9]. In most countries, the institutional arrangement of land administration depends on the local context and the legal framework or the land policy of the country [10]. For instance, China has a dual system of land administration. In China, urban land is owned by the state while rural and peri-urban land are collectively owned by the local community [11,12]. However, the dual institutional arrangement of land has created challenges to transfer land rights. Specifically, rights to use state-owned land can be commercialized, while rights to collectively owned land cannot be sold to anyone as 
a commodity [13]. Accordingly, the dual urban-rural land administration institutional arrangement in China has resulted in significant disparities in income, social welfare and public services between urban and rural residents [14]. In addition, compared with urban areas, rural areas lack investment, infrastructure and economic reforms, which have limited rural economic development and widened the gap between urban and rural development [15]. The dual urban and rural land tenure system has significantly limited the integration of economic and social development in China [14].

In general, the dual urban-rural land administration system in China leads to a different land rights system, an inefficient use of land resources, a rapid conversion of arable land, limited farmers' land rights, land disputes between the two institutions, distorted land markets and social disintegration [15-19]. In Nigeria, the national government is responsible for administering land within an urban area only, while the local government is empowered to administer land outside urban area. The dichotomy of land administration between urban and rural land administration institutions has resulted in problems such as issuance of inappropriate certificate, confused land identification processes and administrative conflicts between the national government and the local government in the country. Unsuitably, there is no clear demarcation of powers and responsibilities of these bodies. Scholars have recommended that there should be no dichotomy between urban and rural land administration and there must be a uniform system in the management of land in Nigeria [10].

In Ethiopia, two separated institutions are responsible for the management of land. Rural land is administered by the Ministry of Agriculture, while urban land is administered by the Ministry of Urban Development and Construction at the federal level. The corresponding regional Bureaus of the two federal ministries are responsible for the urban and rural land administrations separately at the regional levels in most regions of the country. Strengthening Ethiopian land administration system requires a deep understanding of the country's historical, legal and institutional context, as well as contemporary practices [20]. There must be a strong institutional arrangement in both urban and rural land to carry out the land administration functions, as well as to build up sustainable land administration capacity in Ethiopia in general and in Amhara region in particular [2,4,21]. The institutional setup is one of the most crucial aspects that influences the success of land administration systems [2]. Land administration institutions at all levels are key role players in putting the legal and regulatory frameworks into practice [6,22]. A strong co-ordination among service-providing land administration institutions is another key factor for determining the quality of the land administration service delivery for long-term development [23]. The weakest part of Ethiopian land administration institution setup is the institutional dichotomy between urban and rural land [2,9]. Separating institutions into urban and rural land is not based on land administration core processes and key functions in Ethiopia [2].

Scholars argue that most of the land related problems Ethiopia faced are due to the separation of land administration institutions [2,24]. It causes a mismatch of institutional responsibilities, increases the cost of land administration services delivery, lowers the quality of services, complicates co-ordination between separate institutions, makes it difficult to develop common standards for land administration systems and jeopardizes tenure security by causing land records to be neglected $[4,20,24,25]$. Furthermore, institutional separation for urban and rural land leads to inconsistent implementation of land policies on urban and rural land rights and it increases land wastage and illegal occupations, particularly on the outskirts of cities $[2,3,26]$. Above all, the absence of a strong central national institution that gives clear policy, legal, technical and financial guidance for both urban and rural land in an integrated approach has resulted in uncertainty in the country as well as in the region [24]. In addition, some studies such as [2,3,24,27] have tried to indicate the challenges of institutional separation between urban and rural land administration. The above all studies reported indirectly the problem of institutional separation of urban and rural land administration in Ethiopia. However, none of the studies has been conducted with clear set objectives and methods to identify the challenges of institutional 
separation between urban and rural land administration. In addition, the opportunities of institutional separation between urban and rural land administration were not thoroughly addressed by these studies. Accordingly, there is a dearth of studies on the challenges and opportunities of institutional separation between urban and rural land administration in Ethiopia in general and in Amhara region in particular. Therefore, this study could mainly fill these gaps. In this context, the main objective of the study was to identify the major challenges and opportunities of institutional separation between urban and rural land administration in the Amhara region. Specific objectives were to assess the integration of urban and rural land administration institutions for land administration tasks, to identify the challenges caused by the separation of urban and rural land administration, and to identify the opportunities of institutional separation between urban and rural land administration. The study will help the stakeholders and decision-makers to develop harmonize land policy, proclamation, regulation, directive, standards and other working documents. These are imperative for the effective management of both urban and rural land as well as for achieving sustainable development. In addition, the study could be considered as a stimulator for similar investigations worldwide.

The paper is organized as follows: Section 2 describes the institutional structure and the challenges of institutional separation between urban and rural land administration with a focus on the Ethiopian situation. Section 3 presents the study area, the collected data and the research methods. Results are documented in Section 4, whereas discussion and conclusion are presented in Sections 5 and 6, respectively.

\section{Setup of Urban and Rural Land Administration Institutions}

\subsection{Land Administration Institutional Structure in Ethiopia}

Land administration institutions have played a significant role in the history of Ethiopia [4]. Article 51 (5) of the Federal Constitution vests the right to divide the power between the Federal Government and the Regional States for administering land, as well as for enacting legislation governing the use and conservation of land [28]. Under Article 52 (2) (d) of the Federal Constitution, Regional States are given the authority to administer land and other natural resources in conformity with federal laws. Ethiopian current land administration programs are not well co-ordinated at both the national and regional levels [26]. There is no federal institution for urban and rural land administration that can provide consistent support and co-ordination across regions. The nine regional governments have different institutional frameworks at the regional level. Each has taken a unique approach for establishing institutional structures for land administration [26,29]. There is no land policy and administration unit at the national level of government that might function as a co-ordinating organization for policy discussion and to co-ordinate land administration institutions [21,30]. As a result, land administration institutions need to be harmonized to ensure openness at all levels of national government [31].

Land-governing institutions are classified as either urban or rural, with different proclamations, regulations and directives [3]. The land administration institutional setup of Ethiopian rural land management begins from the Ministry of Agriculture and proceeds to the lowest political-administrative hierarchy known as kebele [4]. In Ethiopia, Rural Land Administration and Use Directorate (RLAUD) is responsible for administering rural land in the federal level [4]. The RLAUD has developed a system of Rural Land Administration Information System (NRLAIS) to harmonize rural land registration in the country [32]. It has been co-ordinating the federal rural land administration and use proclamation's implementation by providing national strategic planning and framework, harmonizing and standardizing land administration procedures and processes, harmonizing and coordinating donor activities, and providing technical and financial support for the effective implementations of NRLAIS to the regions [29]. To this end, in the Amhara region, almost all rural landholders have received the first level landholding certificate while the second level landholding certificate is being issued in different parts of the region using the system of NRLAIS [33,34]. 
In terms of the name and institutional structure, each Regional State has its own set of rural land administration institutions [2]. In the Amhara region, the Bureau of Land Administration and Use is responsible for setting the formal rural land administration activities and for ensuring the service delivery. It is accountable to the President of the Amhara Regional State. In the Tigray region, the Regional Environmental Protection Land Administration and Use Authority (EPLAUA) is the key governing authority of rural land administration and is accountable to the Bureau of Agriculture and Rural Development in the region. In the Oromia region, the Bureau of Land and Environmental Protection (OBLEP), accountable to the President of the Oromia region, is the major land administrative authority. In the Oromia region, unlike in other regions of the country, the bureau has the power to administer both urban and rural land [24]. The Oromia bureau of the OBLEP has eliminated the dichotomy of urban and rural land administration by unifying into a single bureau.

On the other hand, in Ethiopia, urban land has been administering by the Department of Land Development and Administration in the Ministry of Urban Development and Construction (MoUDC). Similar to rural land administration, each region in Ethiopia has a different institutional setup and naming of urban land administration institutions. In the Amhara region, for instance, the Bureau of Urban Development and Construction is responsible for urban land. Likewise, other regions of Ethiopia have their own institutional arrangements for urban land [2,20].

\subsection{The Challenges of Institutional Separation for Land Administration in Ethiopia}

The institutional separation of urban and rural land administration systems in Ethiopia is a critical flaw in the institutional structure of the land administration [2]. While Ethiopia is making significant progress in establishing a strong rural land administration system and establishing institutions at various levels, there is clearly a lack of consistency in terms of competence, mandate and progress between urban and rural land administration institutions [24]. The lack of central institution for the management of both urban and rural land, the vast variations in capability between regions and a nearly total institutional isolation between urban and rural land administration have made legislative implementation and service delivery extremely difficult [20]. Land administration has received little attention from higher decision-makers, and as a result, there is no autonomous entity that can administer urban and rural land uniformly. Challenges faced by the urban and rural land administration institutions are policy and legislative gaps, an insufficient institutional capacity, the lack of a harmonized land information system connecting the federal and regional states and a lack of concern by higher decision-makers for land administration [21]. The cost and quality of delivering land administration services are increased by unclear responsibilities for multiple administrative levels or by a mismatch between responsibility and capacity. The lack of a clear description of tasks among administrative levels for urban and rural land administration institutions can also result in an overlap of tasks [24].

As noted above, Ethiopia has two separate land information infrastructure frameworks, one for urban land and the other for rural land. Because of the increased redundancies and contradictions in proclamations, directives and regulations, this setup can be called ineffectual [35]. This dispersion of information sources makes data sharing and dissemination more difficult and to a high degree ineffective, especially in peri-urban land management. Due to these constraints, decision-makers, landholders and other interested parties are unable to obtain needed land information on time [27]. In general, the rural landholding system governs land rights in peri-urban areas. However, due to the increased demand of land for urban purposes, peri-urban areas are under tremendous pressure to be altered to urban land use types [36-39]. Generally, peri-urban landholders are victims of unlawful and unauthorized conversion of agricultural fields into residential areas. They either build substandard houses or offer subdivided plots to people who want to build poor dwellings [27]. The coexistence of numerous overlapping tenure systems is also a feature of peri-urban areas. In the peri-urban areas, informal rights, such as illegal and 
squatters' rights are equally exercised, as are legal rights, such as ownership, leasehold, state grant and customary grants [3]. In the peri-urban areas, institutional fragmentation is often reflected in the uncertain legal rights of land where possession may be disputed with squatters and improvements to it may be made without permission [21]. Starting at the federal level and working down to the local level administration units, both urban and rural land administration organizations have their own workflows and operational capabilities. There is no place for debating about peri-urban land issues other than claiming each other [2]. The institutional separation and lack of co-ordination between urban and rural land administration institutions make it difficult to quickly implement best practices, increases the expense of land administration and restricts the breadth of land management and usage, especially in peri-urban areas [20]. The Amhara region, the Rural Land Administration and Use Bureau, as well as the Urban Development and Construction Bureau, are facing significant difficulty to modify and control land occupation, usage and land markets [2]. Land invasion and the growth of informal settlement in peri-urban areas have been aided by the separation of urban and rural land administration institutions and a lack of co-operation in peri-urban land affairs $[3,36]$.

\section{Data and Methods}

\subsection{Study Area Description}

This study is conducted in East Gojjam, West Gojjam and Awi zones of Amhara National Regional State. These zones are among those with the earliest human settlement center for religious and secular education, richest in natural resources, experienced farming and trade. The East and West Gojjam zones, which are the primary zones that started the early rural land registration system [33]. The East Gojjam zone is found in the northwestern part of Ethiopia in the Amhara Regional State. The East Gojjam zone has an estimated total area of 1.46 million hectares, of which $45 \%$ is arable land and $8 \%$ is irrigated arable land which is suitable for irrigated agriculture. It is an agriculture surplus production area. Furthermore, this area is one of the high potential areas for livestock production in the Amhara region. The total area of the zone is estimated at 14,010 square kilometers, equivalent to 1.4 million hectares [40]. The capital of the East Gojjam Zone is Debre Markos. It is located $300 \mathrm{~km}$ from Addis Ababa and it has 2,451,959 total population (1,199,952 males and 1,252,006 females) [40,41]. The Awi administrative zone is located in northwestern Ethiopia. Injibara is the zonal capital, which is located approximately $455 \mathrm{~km}$ northwest of Addis Ababa. The total area of the Awi zone is 893,520 hectares. Here, 285,232 hectares of arable land, 217,139 hectares belong to pasture and 74,514 hectares to other land use types. The basic livelihoods are forestry and agriculture, which are classified as a mixed agricultural system of crop and livestock production. Average annual rainfall for the Awi Zone is $1750 \mathrm{~mm}$ per year [42]. The West Gojjam Zone has more or less similar physiography with the East Gojjam Zone with a total population of 2,474,254 (1,220,477 men and 1,253,777 women) [41]. Figure 1 shows the location of the study area. 


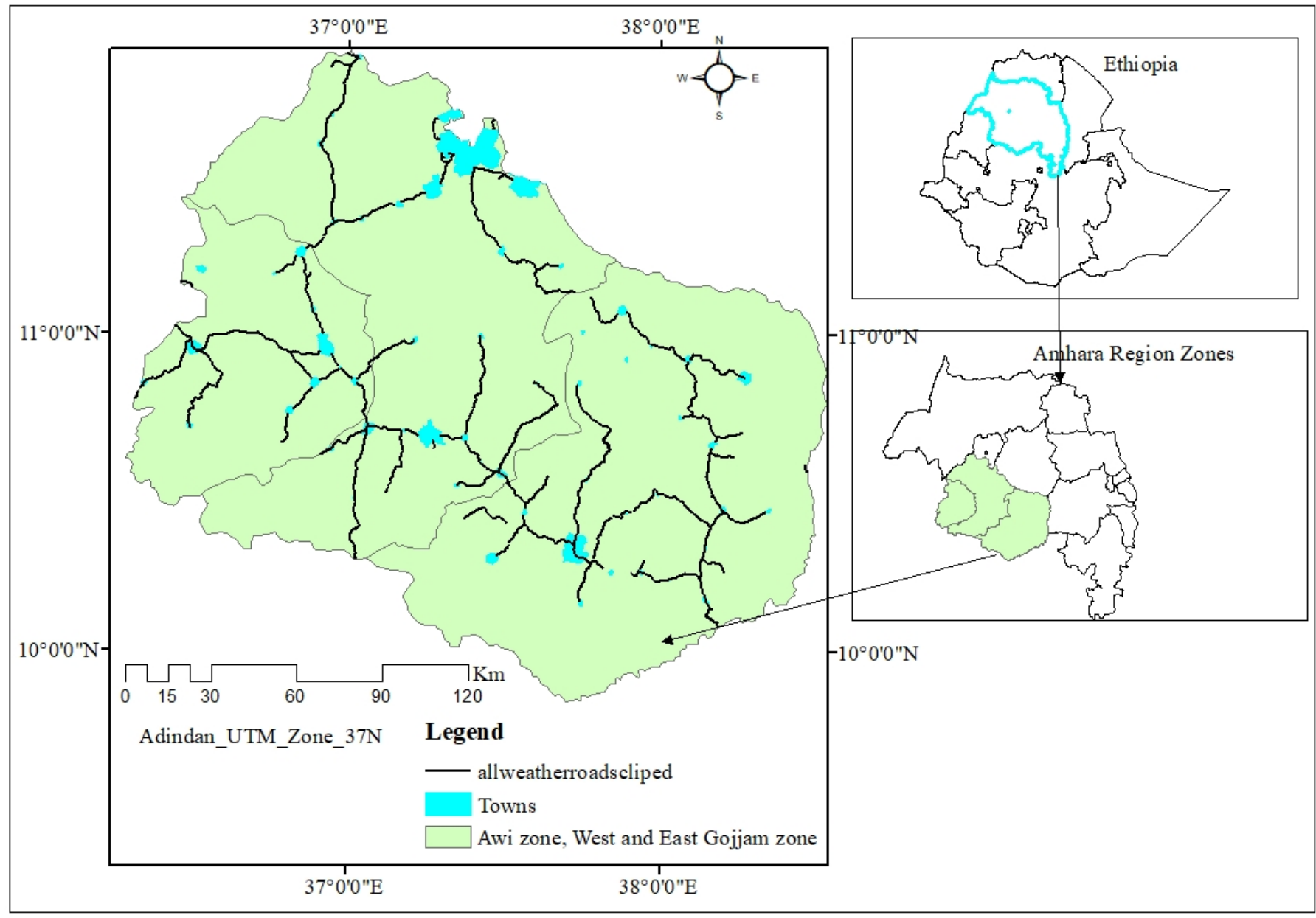

Figure 1. Study area map.

\subsection{Data and Methods of Data Collection}

Both, qualitative and quantitative types of data were collected, and the questionnaire was the main data collection tool for this study. With this regard, open and close-ended questionnaires were administered (Appendix A). The questionnaires included diverse issues that could help understand the perception of land experts and leaders about the land administration system and the challenges and opportunities of existing urban and rural land administration institutions. In addition, the sources of primary data were selected experts from urban and rural land administration institutions of different levels of administration: department heads and leaders of urban and rural land administration institutions at the region, zone and district levels. Together with key informants (land lawyers, experienced land administration professionals, leaders of urban and rural land administration institutions), the experts of institutions participated in focus group discussions (FGD) and provided information by interviews. The FGD is used to assess issues that were not included and answered through the questionnaire as well as for triangulation and exploring further information of the questionnaire survey (see Appendix A). The primary objective of the group discussion was to collect detailed information and to crosscheck with other data collection methods being applied in the study. Eight FGDs were conducted in the selected three zones and the region of urban and rural land administration institutions. In addition, the key informant was the type of interview employed in this study using a semi-structured interview and this helped the researchers to know specific detailed information. Finally, this study also employed document analysis as one of the data collections tools. 


\subsection{Population, Sampling Technique, and Sample Size}

The population of the study consists of all land administration workers in the study areas constituting 757 sample frame. This study applied a purposive sampling technique to select the three zones and the regional level land administration institutions, as there is homogeneity of the land administration institutions in the Amhara region. The land administration institutions are stratified into urban land administration institutions and rural land administration institution according to the type of land they administer. From the urban land administration of the East Gojjam administrative zone, four low-level and one middle level offices, as well as adjacent offices of the same scenario from the rural land administration were purposively selected for the study. Similarly, from the West Gojjam administrative zone, five low-level and one middle-level urban land administration offices with adjacent rural land administration offices were selected purposely. From the Awi administrative zone too, one medium-level and two low-level urban land administration offices with adjacent rural land offices were selected purposively. Finally, in the region, rural and urban land administration bureaus are selected purposely. In these towns, urban areas are expanding rapidly and there is a high level of investment in urban and peri-urban interface. Then, the sample respondents were selected using simple random techniques from the selected target population.

The study has used the following sample size determination formula to set the actual sample size scientifically [43].

$$
n=\frac{N}{1+N\left(e^{2}\right)}
$$

where $n=$ the actual sample size, $N=$ the total population, $e=$ degree of accuracy usually set at 0.05 .

Based on this formula, the sample size obtained as 262 (Equation (2)):

$$
n=\frac{757}{1+757\left(0.05^{2}\right)}=262
$$

The proportional sample size for each stratum was determined based on their population using (Equation (3)) below:

$$
n_{j}=\left(\frac{N_{j}}{N}\right) * n
$$

where $n_{j}=$ size of the sample from the $j$ th stratum, $N_{j}=$ total population in $j$ th stratum, $N=$ total population size, and $n=$ total sample size.

Therefore, 37 and 21 respondents were involved in rural and urban land administration institutions of the Awi zone, respectively. Among the urban and rural land administration institutions of the East Gojjam zone, there were 28 and 36 respondents; in the West Gojjam zone, 37 and 44 respondents were selected from urban and rural land administration institutions. Finally, 33 and 26 respondents participated in questionnaires at urban and rural land administration institutions of the regional levels. Eight FGDs with 12 purposely selected members in each FGDs were conducted in the selected three zones and the region of urban and rural land administration institutions. In addition, the researchers purposively selected 20 key informants based upon the position and work experience of the professionals from each zone and region.

Both qualitative and quantitative methods of data analysis were employed. Quantitative data gathered from the questionnaires were analyzed descriptively and presented using tables, bar graphs and percentages to enable easy interpretation and quick visual comparisons of variables. On the other hand, information obtained from key informants and focus group discussions were analyzed qualitatively to support the quantitative data collected from questionnaire respondents. 


\section{Results}

\subsection{Information of the Study Participants}

About $26 \%$ of the respondents in urban land administration institutions are females, whereas $74 \%$ are males. Similarly, $33 \%$ of the respondents are females and $67 \%$ of them are males from rural land administration offices (Table 1). In total, $29 \%$ and $71 \%$ of the respondents are females and males, respectively, in both urban and rural land administration institutions. About $50 \%$ of the respondents are between $21-35$ years of age. Similarly, $44 \%$ of the respondents were between $36-50$ years of age and the rest (6\%) of the respondents are between 51-65 years of the age. Regarding the educational level, $30 \%$ of the respondents have a diploma, $60 \%$ have a first degree and the rest $10 \%$ have a master's degree.

Table 1. Characteristics of the study participants.

\begin{tabular}{|c|c|c|c|c|c|c|}
\hline \multirow{2}{*}{ Study Participants } & \multirow{2}{*}{\multicolumn{2}{|c|}{ Background }} & \multicolumn{2}{|c|}{ Frequency } & \multicolumn{2}{|c|}{ Percent } \\
\hline & & & Urban & Rural & Urban & Rural \\
\hline \multirow{11}{*}{ 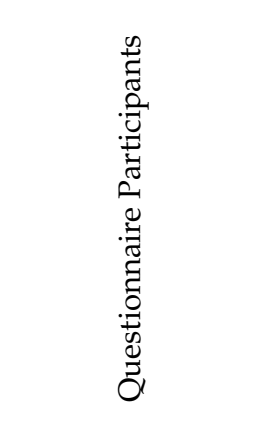 } & \multirow{4}{*}{ 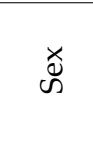 } & Female & 32 & 45 & 25.6 & 32.8 \\
\hline & & Male & 93 & 92 & 74.4 & 67.2 \\
\hline & & Total & 125 & 137 & 100 & 100 \\
\hline & & $21-35$ & 64 & 65 & 51.2 & 47.4 \\
\hline & \multirow{3}{*}{$\underset{\pi}{\infty}$} & $36-50$ & 51 & 65 & 40.8 & 47.4 \\
\hline & & $51-65$ & 10 & 7 & 8 & 5.1 \\
\hline & & Total & 125 & 137 & 100 & 100 \\
\hline & \multirow{5}{*}{ 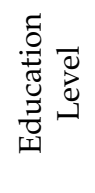 } & Diploma & 38 & 40 & 30.4 & 29.2 \\
\hline & & First Degree & 74 & 81 & 59.2 & 59.1 \\
\hline & & Masters and above & 13 & 16 & 10.4 & 11.7 \\
\hline & & Total & 125 & 137 & 100 & 100 \\
\hline \multirow{4}{*}{ Group Discussants } & & Female & 15 & 10 & 27.27 & 24.39 \\
\hline & \multirow[t]{2}{*}{ Sex } & Male & 40 & 31 & 72.73 & 75.61 \\
\hline & & Total & 55 & 41 & 57.29 & 42.71 \\
\hline & \multirow{3}{*}{ Sex } & Female & 4 & 3 & 33 & 37.5 \\
\hline \multirow[t]{2}{*}{ Key Informants } & & Male & 8 & 5 & 67 & 62.5 \\
\hline & & Total & 12 & 8 & 60 & 40 \\
\hline
\end{tabular}

Source: Experts survey, 2021.

\subsection{The Integration of Urban and Rural Land Administration Institutions}

Around $55 \%$ of the respondents believe that the integration of urban and rural land administration institutions is loose. Thus, according to the survey results of the respondents, the integration between urban and rural land administration institutions is weak. Similarly, $38 \%$ of the respondents confirmed that the integration between the two independent institutions is very weak. On the other hand, $5 \%$ and 3\% of the respondents believe that the relationship between urban and rural land administration institutions is strong and very strong, respectively (Table 2).

Table 2. The integration of urban and rural land administration institutions.

\begin{tabular}{|c|c|c|}
\hline $\begin{array}{l}\text { How You Express the Rural and Urban Land Administration } \\
\text { Institutions Integrations towards Administering Land }\end{array}$ & Frequency & Percent \\
\hline Very Strong & 7 & 2.67 \\
\hline Strong & 12 & 4.58 \\
\hline Weak & 143 & 54.58 \\
\hline Very Weak & 100 & 38.17 \\
\hline Total & 262 & 100.0 \\
\hline
\end{tabular}

Source: Experts survey, $n=262,2021$.

The results from the key informants and discussants showed that urban and rural land administration institutions have not integrated land administration system. As they discussed, due to the different visions, missions and objectives of these institutions, there 
are many overlapping and conflicting interests, such as land use mainly in peri-urban areas. With respect to peri-urban areas, urban land administration institutions sued rural land administration institutions and vice versa. The respondents of key informants and discussants from rural land administration institutions said that urban land administration institutions have no sense of responsibility for peri-urban farmers. The currently responsible institution for the administration of urban land, the Ministry of Urban Development and Construction, did not give adequate focus for land in the peri-urban areas. Even the term "land" is not included in their nomenclature. The key informants and discussants of rural land administration institutions argued that urban land must not be administered in this institution. On the contrary, the discussants, and key informants of urban land administration institutions argued that rural land administration institutions gave unreasonable preferential treatment for peri-urban farmers. They emphasized that the rural land administration institutions impose very high compensation during expropriation. In addition, they have been increasing the transaction of land around peri-urban land areas. This implies that both institutions have repealed each other rather than working together jointly for the same objective.

The group discussants and key informants pointed out that there has been an increasing informal settlement in the study of peri-urban areas due to a lack of co-ordination between urban and rural land administration institutions. According to them, the weak co-ordination of the two institutions results in increasing land invasions and informal settlements in the peri-urban areas. They added that in the current structure of land administration institutions, rather than administering the land by integrating each other, repelling each other has been observed and it is difficult to solve the problem of repelling each other because each institution has their own proclamations, directives and regulations that can support their own priorities. Additionally, concerning peri-urban land, the responsibilities of urban and rural land administration institutions are not defined clearly.

\subsection{The Major Challenges of the Institutional Dichotomy}

\subsubsection{Contradicting Legislations}

The institutions of both urban and rural land have their own proclamations as well as concomitant regulations and directives. Because of the disintegration of both institutions towards administering land, the proclamations, regulations and directives raised by both institutions have contradictory ideas with each other. As an example, we can take urban land lease holding proclamation Number 721/2011 article 2 sub-article 2 which states that "urban land" means land located within an administrative boundary of an urban center. Regulation Number 103/2012 of the proclamation under article 2 (1) and directive Number 1/2012 under article 2 (4) also agreed with this definition. On the contrary, the revised rural land administration and use determination proclamation Number 252/2017 article 2 sub-article 1 of the Amhara National Regional State states that "rural land" means a rural landholding found within the limit of a rural land administration and any other rural land that may be found in cities administration and plan boundary [44-47]. Therefore, the definitions of rural and urban land have an ambiguous meaning. From the definitions, according to proclamation Number 721/2011 and proclamation Number 252/2017, a common land lays in both urban land administration boundary and rural land administration boundary. However, the proclamations said nothing about the responsible institution of this peri-urban interfaces $[44,47]$. Concerning these and according to the discussants, there are some parcels under urban land administration boundary and urban plan boundary but being administered by rural land administration institutions. In this case, there is a conflict of interest on the use of land between urban and rural land administration institutions. The key informants and discussants also declared that the property valuation guidelines used by both institutions are different. In this context, rural land administration institutions considered compensation for trees and displacement compensation for land that is taken for road construction. However, urban land administration institutions were not giving any compensation for trees and land expropriated for the construction of public road. All 
key informants and discussants confirmed that administering both urban and rural land by a unified institution could help to have consistent working guidelines for the institutions.

\subsubsection{Boundary and Interest Disputes}

Almost all respondents agreed that there is a boundary dispute between urban and rural land administration institutions. In addition, key informants and discussants attested no clear boundaries between urban and rural land though urban areas are expanding spatially. As a result, there are always boundary disputes between urban and rural land administration institutions.

Urban and rural land administration institutions have their own vision, mission and goals. Likewise, they have different interests in administering the land. The key informants and discussants pointed out that the institutional separation between urban and rural land causes different interests in urban and rural land administration institutions. In most cases, contradicting interests on the use of land between the institutions have been observed in peri-urban areas. Most of the respondents also agreed that different interests have been observed between urban and rural land administration institutions during the peri-urban land administration.

\subsubsection{Scarcity and Wastage of Resources}

According to the assessment of this study, the institutional arrangement of the land administration of both urban and rural land is not organized based on the core land administration functions. The majority of the respondents described that in the structures of both urban and rural land administration organizations, there are overlapping job titles and other responsibilities. The key informants and discussants also stated that urban and rural land administration institutions have their own land administrators, surveyors, GIS experts, real property valuation experts, land law experts, urban planners and other related professionals. According to them, even though the institutional structure of land administration is not based on the core functions of the land. Most job titles are similar in both urban and rural land administration institutions. Consequently, there are inefficiencies of human and material resources.

On the other side, the majority of respondents of rural land administration institutions recognized shortages of human resources in rural land administration institutions. In addition, both urban and rural land administration institutions key informants described that there are also shortages of material resources in their institutions such as surveying instruments. Surprisingly, key informants confirmed that the salaries of the experts in the same job titles are different in urban and rural land administration institutions. The key informants from rural land administration institutions strongly argued that the government did not give focus to rural land administration institutions concerning the payments of the experts. They further added that even though the land administration institutions have been collecting very high income from the land for the government, the amount of budget being allocated for the rural land administration institutions is very low compared to other sectors such as education, health and so on. Similarly, the key informants from urban land administration institutions claimed that the annual budget allocation for urban land administration institutions is low.

\subsubsection{Different Land Registration Systems}

Most of the respondents confirmed that there is a different land registration system between urban and rural land administration institutions in the region. In this context, key informants from rural land administration institutions recognized that there is an effective implementation of rural land cadaster in the region. On the contrary, key informants of urban land administration institutions confirmed that the implementation of urban land cadaster is not effective until now. According to the key informants from urban land administration institutions, urban land registration was conducted independently from the rural land registration system. They stated that there is a lack of finance to undertake 
region wide urban land registration. With this regard, investigations of the current study give evidence that urban and rural land administration institutions have their own and different land registration systems. Due to incompatible formats, transferring of land from the system of rural holding rights to urban lease rights is very difficult, particularly in peri-urban areas. Key informants and discussants agreed that administering land by a single institution would help to harmonize the land registration systems of urban and rural land in the region as well as in the country.

\subsection{The Major Opportunities of the Institutional Dichotomy}

In the findings of this study, many challenges of institutional separation between urban and rural land administration are analyzed. However, respondents, key informants and discussants of both institutions identified very few opportunities for institutional separation between urban and rural land administration. Accordingly, the findings of the study identified some of the opportunities for the dichotomy between urban and rural land administration. In this context, based on the key informants and discussants of rural land administration institutions, there is well-established institutional structure of rural land administration organization in the region. Additionally, the key informants and discussants of both institutions confirmed that administering urban and rural land by different institutions enables fast services for the customers in case of clear responsibilities between urban and rural land administration institutions. In addition, the institutional separation between urban and rural land administration will help to minimize the workload in each of the institutions. Moreover, some of the key informants also argued that since urban and rural land have their own features, administering urban and rural land by different institutions considering their features enables them to administer land properly.

\subsection{Structure of Land Administration Institutions}

The findings of the current study identified that the institutional separation for urban and rural land has many challenges that prevent the administration of land effectively and efficiently. The respondents, key informants and discussants of both institutions confirmed that the reason for the separation of land administration is due to different proclamations, regulations and directives for urban and rural land. However, most of them believed that the current institutional structure of the land has to be changed and organized based on the core functions of the land. About $73 \%$ of the respondents agreed that both urban and rural land have to be administered by a unified institution, while only $27 \%$ believed that urban and rural land have to be administered separately by different institutions (Table 3 ).

Table 3. Administering of land by the same institution.

\begin{tabular}{ccc}
\hline $\begin{array}{c}\text { Do You Believe that Unified Institution Can } \\
\text { Administer Urban and Rural Land? }\end{array}$ & Frequency & Percent \\
\hline Yes & 191 & 73 \\
No & 71 & 27 \\
Total & 262 & 100 \\
\hline
\end{tabular}

Source: Experts survey, $n=262,2021$.

Similarly, $88 \%$ of the respondents reported that land should be organized at Ministry level, whereas $12 \%$ responded that the current organizational structure is enough (Table 4). The key informants and discussants of both urban and rural land administration institutions strongly believe that urban and rural land have to be administered by a unified institution and there should be one independent ministry, which is responsible for urban and rural land. Moreover, if there is one responsible ministry at the federal level, there will not be contradicted proclamations, regulations and directives; the integration between urban and rural land will be strong and the conflict of interest between urban and rural land administration institutions will be highly minimized. 
Table 4. Administering of land by Ministry level.

\begin{tabular}{rcc}
\hline $\begin{array}{c}\text { Do You Believe that Land Has to Be } \\
\text { Administered by Separate Ministry? }\end{array}$ & Frequency & Percent \\
\hline Yes & 230 & 88 \\
No & 32 & 12 \\
Total & 262 & 100 \\
\hline Source: Experts survey, $n=262,2021$. &
\end{tabular}

According to the respondents of urban land administration institutions, rural and urban land have different characteristics. Almost all the respondents confirmed that there is a difference in the use between urban and rural land. However, according to them, this difference could not lead to having different institutions for both urban and rural land administration. About $67 \%$ of the respondents recommended that a single institution should manage both urban and rural land. Most of the respondents of urban land administration institutions agreed that administering urban and rural land by unified institution could minimize the current problems faced in administering of land both in urban and rural areas. In line with this, key informants and discussants of urban land administration institutions added that the institutional separation between urban and rural land is not justifiable. They believed that even though urban and rural land have different characteristics, a unified institution could administer both urban and rural land. Key informants and discussants also agreed that urban and rural land administration institutions have unique responsibilities. However, if there is a unified institution for both urban and rural land, the duties and activities of urban and rural land administration institutions will be covered properly. Most of the experts agreed that the current problem faced in both institutions is caused by the dichotomy of instructional structures of the region and the country as well. To summarize, they recommend a unified institution being responsible and accountable for both urban and rural land (see Figure 2).

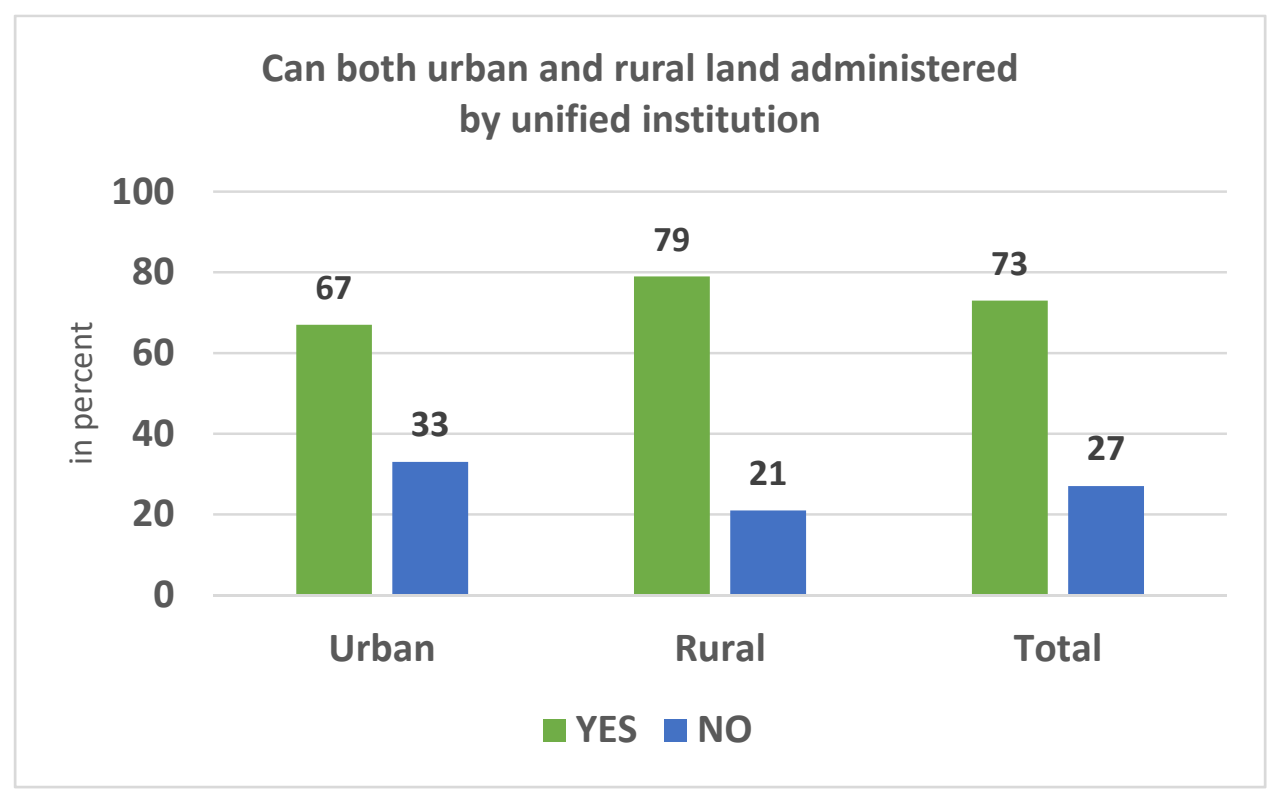

Figure 2. Perception of respondents about the unification of land administration institution. Source: urban land and rural administration experts survey, $n=125$, and $n=137$, respectively, 2021.

Similarly, about $76 \%$ of interviewees of rural land administration institutions indicated that there is a difference of use between urban and rural land, while $24 \%$ of the respondents recognize no difference between urban and rural land (see Figure 2). About $79 \%$ of the respondents revealed that the difference between urban and rural land could not lead to having different institutions for urban and rural land management. Most of the respondents 
also indicated that many overlapping activities have been conducting by both urban and rural land administration institutions. Most of the respondents of rural land administration institutions are convinced administering urban and rural land by a single institution could minimize the current problems faced in rural land administration institutions. The key informants in these institutions reasoned out that urban and rural land have interlinked features. As urban expansion ultimately engulfs rural land, administering both land types with the same institution is better. Additionally, there are identical tasks for the urban and rural land administrations. For instance, there is an institutional structure of rural land development and urban land development for rural and urban land administration institutions, respectively. This results in redundancy of tasks and extravagancy of resources. Moreover, having two different institutions for the management of urban and rural land will lead to a corrupted system. According to the key informants from rural land administration institutions, many problems have been faced such as a poor file management system, problems in implementing regulations, incompatibilities of rules and regulations between urban and rural land, and landlessness of peri-urban landholders.

\section{Discussion}

The 1995 Federal Constitution gave urban and rural land ownership to the state and the people of Ethiopia and the Regional States had the right to administer the land [28]. However, the constitution did not mention how all regions of Ethiopia administer urban and rural land uniformly. Because of this, all regions have different land administration institutions for administering urban and rural land [34]. The current study reported that because of the different land administration institutions for urban and rural land in the Amhara region, land grabbing and informal settlement have been increasing in all urban areas of the region. In line with this, the studies made by [2,3] reported that land grabbing by investors and unplanned settlement by informal settlers are the main challenges in the Amhara region. Each institute pursues to secure their interest, they have their own activities and workflows, and they enforce decisions in different ways in the same land. As a result, there is an institutional-based conflict over the land [2]. In line with this, the studies conducted in China reported that there is land conflict between land administration institutions $[15,17,19]$. Similarly, there are overlapping issues in the legal frameworks for urban and rural land [30,32]. Accordingly, China's urban and rural land administration institutions operate with overlapping powers, functions and jurisdictions $[16,18]$.

The existence of conflict of interest between the urban and rural land administration institutions is also corresponded with the findings of other studies [2,3,26,35,48]. One notable example is that urban land policy favors a market-oriented lease system for a set period, while rural land policy favors a freehold right with no payment and no time limit [35,48]. Within the government, there are no consistent special organizations in charge of land administration. As a result, several departments of the government have enacted many inconsistent land legislations, which are limiting land administration effectiveness [26].

This study identified that mutual land has existed in both urban and rural land administration boundaries in peri-urban areas. However, the proclamations said nothing about the responsible intuitions for the peri-urban areas as documented in other studies too $[20,24]$. The findings of this study revealed that there are no uniform standards between urban and rural land administration institutions and the system is fragmented and expensive. This absence also leads to the neglect of rural land records during urbanization, which is a severe problem that jeopardizes tenure security $[20,30,36,49]$. In addition, the responsibilities of urban and rural land administration institutions are not clearly defined in peri-urban areas, which are in line with the findings of similar studies $[2,4,27]$.

In line with this study, other studies [3,20,21,24,29] highlighted shortcomings in the integration between urban and rural land administration institutions during the administering of the land. The current study also found that there is no national institution that gives clear legislative, legal, technical and financial guidance for both rural and urban land in an integrated way. Thus, there is duplication of efforts, material and human resources in 
land administration institutions. On the other side, there is sometimes a lack of human, material and financial resources $[4,20,24]$. Additionally, the institutional separation between urban and rural land administration institutions can result in increased expenses, data inconsistencies, and, as a result, inaccuracies, and a risk of confusion leading to erroneous decisions [50] and the same result has been reported by the current study.

According to the current study results, the institutional structure of both urban and rural land is not based on the core functions of the land. In line with this finding, the study made by [2] found that the institutional structure is not based on the main functions of land value, land use, land tenure and land development. This study found that fragmentation of land information between urban and rural land administration institutions is the main challenge in the region. In addition, the findings of this study showed that urban and rural land administration institutions have their own land registration system with different standards and procedures in the region and the system is not compatible. In this context, the study conducted by [35] reported that there are different registration systems for urban and rural land and the systems are incompatible to transfer the registered land from urban land administration institution to rural land administration institution or vice versa, which is in line with the findings of the current study.

This study documents a lack of harmonized land proclamations, regulations and directives for both urban and rural land administration institutions in the Amhara region since both institutions have followed their own procedures, standards, rules and working guidelines. In line with this study result, the study [20,25] reported that lack of institutional co-ordination and policy harmonization contribute to poor land governance. Other studies also reported that the roles and mandates of the two land administration institutions at each administrative level are not clearly defined.

Most of the respondents, key informants and discussants of both institutions believed that there should be an independent institution that is responsible for both urban and rural land. As they discussed, a separate and independent ministry must administer land and there should be harmonized land policy for both urban and rural land in the region and in the country as well. Similarly, many studies confirmed that both urban and rural land have to be administered by an independent institution [2-4,21,24,25,29]. In a similar way, a study conducted in Nigeria [10] recommended that unified land administration system is appropriate for administering both urban and rural land.

This study discussed the institutional separation of urban and rural land administrations in the Amhara region and the results identified many challenges. In this regard, some studies too have pointed out the challenges of separating urban and rural land administration $[2,4,12,25,37]$. This study examined the opportunities for institutional separation of land administration for urban and rural land in addition to the challenges. However, as identified in this research, the challenges overshadow the opportunities.

\section{Conclusions, Implications, Limitations and Future Works}

This study confirmed that there are different institutional structures for urban and rural land administration with their own vision, mission and objectives in the Amhara region. The weak integration between urban and rural land administration institutions is the key challenge that prevents the efficient and effective land administration mainly in peri-urban areas of Amhara region. The institutional separation between urban and rural land administration has opened the door for land invasion and informal settlement in peri-urban areas. In peri-urban areas, the different institutional structures of both urban and rural land administration caused boundary and interest-based disputes between urban and rural land administration institutions. Consequently, peri-urban landholders have faced different problems such as unable to get services timely.

The absence of strong national land administration institution for both urban and rural land has resulted contradicted proclamations, regulations and directives between urban and rural land administration institutions. In addition, there are different land registration systems between urban and rural land with incompatible formats to undertake 
digital transaction. There is also wastage of material, human and financial resources in the institutions. On the contrary, there are shortages of human, material and financial resources. The findings confirmed that there must be one independent institution responsible for both urban and rural land in the country. The institutional separation between urban and rural land administration has the opportunity of minimizing workload and facilitating land administration service provisions for the customers in case of clear responsibility between the urban and rural land administration institutions. Based on the findings of this study, the researchers forwarded the following recommendations:

- The regional government must resolve the contradictory proclamations, regulations and directives and modify them in the region and the country as well.

- An independent institution at the ministry level should administer both urban and rural land in the region and the country. For the co-ordinated and effective execution of land administration functions and for land administration to contribute to the sustainable development of the nation, it is imperative to have the ministry of land and spatial planning and the rural and urban land administrations can be organized at the state ministry level.

- There should be a harmonized land policy, proclamations, regulations, directives, standards, working guidelines and institutional arrangements for both urban and rural land across the regions of Ethiopia.

- The institutional structure of both urban and rural land administration institutions should be arranged based on the core functions of the land.

- The government has to strengthen the land administration sector in both the region and the country.

The current study investigated the challenges and opportunities of the institutional dichotomy of the land administration, taking samples from Awi, West and East Gojjam administrative zones in the Amhara region. The findings of the study have tried to identify the major challenges and opportunities of institutional separation between urban and rural land administration in the region. The findings revealed that there is no uniform institutional structure of land administration across the regions in Ethiopia. Therefore, further study could be conducted for other regions of Ethiopia to harmonize land policy and institutional arrangements of land in the country. Moreover, the comparative study should be conducted between a dual urban-rural land administration system and a unified land administration system in the future.

Author Contributions: Conceptualization: W.N., M.T., Y.H., S.K.A., R.M.; formal analysis: W.N., Y.H., S.K.A., R.M.; publication funding acquisition: S.K.A., R.M.; methodology: W.N., M.T., Y.H., S.K.A., R.M.; supervision: Y.H., M.T.; validation: Y.H., M.T.; visualization: W.N., M.T., Y.H., S.K.A., R.M.; writing—original draft: W.N.; writing—review and editing: W.N., Y.H., M.T., S.K.A., R.M. All authors have read and agreed to the published version of the manuscript.

Funding: This study was funded by Debre Markos University and EduLAND2 project fund.

Institutional Review Board Statement: All respondents of questionnaire and all participants of focus group discussions and key experts' interviews are not mentioned by name. Results are aggregated and cannot be traced back to individual persons.

Informed Consent Statement: All persons involved in the study participated voluntary and agreed the publication of results derived from their responses.

Data Availability Statement: Not applicable.

Conflicts of Interest: The authors declare no conflict of interest.

\section{Appendix A}

Survey questionnaire for urban and rural land administration institutions experts Part I: Respondent's profile

1. Name (optional) age 
2. Sex 1. Female 2. Male

3. Educational level

4. Address (kebele)

5. Your job

6. Position

7. Working organization

8. Profession

Part II: General questions

General guideline

Please put $\mathrm{x}$ sign for your choice from the alternatives for each question, and you can choose more than one answer accordingly.

1. Do you believe that there is difference between urban and rural land?
A. Yes

2. NoIf your answer is "yes" from Q 1, do you believe that the difference of urban and rural land can lead to having different institutions for urban and rural land?
A. Yes

3. NoDo urban land administration institutions have different responsibilities from rural land administration institutions?
A. Yes, they have
B. No, they have not
C. I don't know

4. Do you believe that the responsibility of urban land administration institutions can be conducted by rural land administration institutions? Or vice versa?
A. Yes, it can be conducted
B. No, it can not
C. I don't know

5. Is there any clear responsibility of urban and rural land administration institutions regarding peri-urban areas?
A. Yes
B. No

6. How do you express the rural and urban land administration institutions integrations towards administering land?
A. Very strong
B. Strong
C. Very weak
D. Weak

7. If urban and rural land were to be administered separately by different institutions:
A. There may be different rules and regulations for urban and rural land adminis- tration institutions which may have conflicting interests
B. It may be difficult to administer urban and rural land in a uniform way
C. It may be difficult to administer urban and rural land effectively
D. There may be the dissipation of resources

8. Which of the following problems may be caused by the separation between urban and rural land administration institutions?
A. Boundary conflict
B. Interest conflict
C. Lack of resource/Waste of resources
D. Conflict of laws
E. If other, specify 
9. Do you believe that administering urban and rural land by the same institution can minimize the current problems?
A. Yes
B. No

10. Do you believe that land has to administer by the same institution?

A. Yes

11. NoDo you believe that land has to be administered at a ministry level?

A. Yes

B. No

12. What are the challenges of the institutional separation between urban and rural land administration institutions?

13. What are the opportunities of the institutional separation between urban and rural land administration institutions?

Questionnaire for focus group discussants and key informants for both urban and rural land administration institutions

1. What are the challenges of the institutional separation between urban and rural land administration institutions?

2. What are the opportunities of the institutional separation between urban and rural land administration institutions?

3. How do urban and rural land administration institutions integrate to work on land administration issues?

4. From your perspective, what improvements should be made on the existing urban and rural land administration institutions?

5. What are your suggestions about the structure of urban and rural land administration institutions in the future?

6. What challenges will be faced if urban and rural land administration institutions come together to a single institution?

\section{References}

1. Subedi, G.P. Land Administration and Its Impact on Economic Development; University of Reading: Kuala Lumpur, Malaysia, 2016.

2. Shibeshi, G.B.; Fuchs, H.; Mansberger, R. Lessons from systematic evaluation of land administration systems. the case of amhara national regional state of Ethiopia. World Dev. 2015, 68, 282-295. [CrossRef]

3. Adam, A.G. Informal settlements in the peri-urban areas of Bahir Dar, Ethiopia: An institutional analysis. Habitat Int. 2014, 43, 90-97. [CrossRef]

4. Adam, A.G.; Birhanu, T.A. Decentralised Rural Land Administration in Ethiopia: The Case of Amhara Region. J. Land Rural. Stud. 2018, 6, 34-49. [CrossRef]

5. Enemark, S.; Williamson, I.; Wallace, J. Building modern land administration systems in developed economies. J. Spat. Sci. 2005, 50, 51-68. [CrossRef]

6. Klimach, A.; Dawidowicz, A.; Źróbek, R. The Polish land administration system supporting good governance. Land Use Policy 2018, 79, 547-555. [CrossRef]

7. Wubneh, M. Policies and praxis of land acquisition, use, and development in Ethiopia. Land Use Policy 2018, 73, 170-183. [CrossRef]

8. Dawidowicz, A.; Voß, W.; Leonard, B. Land Administration Systems Development Trends-A Case Study. Real Estate Manag. Valuat. 2013, 21, 83-92. [CrossRef]

9. Haile, S.A.; Mansberger, R. Land Policy, Urban-Rural Interaction and Land Administration Differentiation in Ethiopia. In Proceedings of the Second FIG Regional Conference, Marrakech, Morocco, 2-5 December 2003.

10. Otubu, A. The land use act and land administration in 21st century Nigeria: Need for reforms. J. Sustain. Dev. Law Policy 2018, 9 , 80-108. [CrossRef]

11. Yang, R.; Yang, Q. Restructuring the State: Policy Transition of Construction Land Supply in Urban and Rural China. Land 2021, 10, 15. [CrossRef]

12. Yuan, D.; Yau, Y.; Bao, H.; Liu, Y.; Liu, T. Anatomizing the institutional arrangements of urban village redevelopment: Case studies in Guangzhou, China. Sustainability 2019, 11, 3376. [CrossRef]

13. Wang, M.; Yang, Y.; Guo, T. Measurement of Urban-Rural Integration Level in Suburbs and Exurbs of Big Cities Based on Land-Use Change in Inland China: Chengdu. Land 2021, 10, 474. [CrossRef] 
14. Zhou, Y.; Li, X.; Liu, Y. Rural land system reforms in China: History, issues, measures and prospects. Land Use Policy 2020, 91, 104330. [CrossRef]

15. Li, L.-H. Balancing rural and urban development: Applying coordinated urban-rural development (CURD) strategy to achieve sustainable urbanisation in China. Sustainability 2017, 9, 1948. [CrossRef]

16. Shan, L.; Ann, T.; Wu, Y. Strategies for risk management in urban-rural conflict: Two case studies of land acquisition in urbanising China. Habitat Int. 2017, 59, 90-100. [CrossRef] [PubMed]

17. Chen, K.; Long, H.; Liao, L.; Tu, S.; Li, T. Land use transitions and urban-rural integrated development: Theoretical framework and China's evidence. Land Use Policy 2020, 92, 104465. [CrossRef]

18. Liu, Z.; Liang, M. Study on dual-track system of Chinese land ownership. Cross-Cult. Commun. 2015, 11, 24-28.

19. Chen, J. Obstacles and Countermeasures For Building Unified Urban and Rural Construction Land Market. Cross-Cult. Commun. 2015, 11, 127-132.

20. FDRE. Options for Strengthening Land Administration. 2008. Available online: https:/ / openknowledge.worldbank.org/handle/ 10986/2721 (accessed on 13 February 2021).

21. Belay, A.A. Ethiopian federal rural land administration institution practices, challenges, gaps and recommendations. Int. Rev. Humanit. Sci. Res. 2017, 287-306. Available online: http://irhsr.org/papers/Jun2017-10.pdf (accessed on 2 April 2021).

22. Larden, D.; Sullivan, M. Strengthening land administration in Solomon Islands. Vol. Two 2008, 307-324. Available online: https:/ / www.dfat.gov.au/sites/default/files/MLW_VolumeTwo_CaseStudy_15.pdf (accessed on 21 March 2021).

23. Olira, K. Urban Land Administration Practices in Emerging Cities of Ethiopia: The Case of Shashemene City of Oromia Regional State, Southern Ethiopia. Int. J. Curr. Res. 2017, 9, 47641-47649.

24. Belachew, M.; Ethiopia, S.A. Facing the challenges in building sustainable land administration capacity in Ethiopia. In Proceedings of the Facing the Challenges-Building the Capacity, Sydney, Australia, 11-16 April 2010; pp. 11-16.

25. Ariti, A.T.; van Vliet, J.; Verburg, P.H. The role of institutional actors and their interactions in the land use policy making process in Ethiopia. J. Environ. Manag. 2019, 237, 235-246. [CrossRef]

26. Adgo, E.; Selassie, Y.G.; Tsegaye, S.A.; Ayele, A.A. Impact of land certification on sustainable land resource management in the Amhara region, Ethiopia. Retrieved Sept. 2014, 21, 2015.

27. Adam, A.G. Land Tenure in the Changing Peri-Urban Areas of E thiopia: The Case of Bahir Dar City. Int. J. Urban Reg. Res. 2014, 38, 1970-1984. [CrossRef]

28. FDRE. Constitution; Negarit Gazata: Addis Ababa, Ethiopia, 1995.

29. Zerga, B. Land Resource, Uses, and Ownership in Ethiopia: Past, Present and Future. Int. J. Sci. Res. Eng. Technol. 2016, 2, 17-24.

30. Belay, K. Question regarding rural land ownership rights in Ethiopia. J. Rural. Dev. Nongchon-Gyeongje 2003, $26,99-134$.

31. Tarek, Z.; Abza, T.G.; Tenno, T.; Reda, Y.; Abera, A. The Innovative National Rural Land Administration Information System of Ethiopia. In Proceedings of the World Bank Conference on Land and Poverty, Washington, DC, USA, 25-29 March 2019.

32. Takele, A. Ethiopian Urban Land Lease Policy Analysis Implementation: Case Study on AA City Administration. Int. J. Soc. Sci. Perspect. 2018, 2, 96-100. [CrossRef]

33. Tsegaye, G.; Dessalegn, M. The role of rural land registration and certification program for land tenure security in Hulet Eju Enese District, Amhara National Regional State, Northwest Ethiopia. J. Agric. Ext. Rural. Dev. 2017, 9, $215-222$.

34. Bezu, S.; Holden, S. Demand for second-stage land certification in Ethiopia: Evidence from household panel data. Land Use Policy 2014, 41, 193-205. [CrossRef]

35. Wubie, A.M.; de Vries, W.T.; Alemie, B.K. Synthesizing the dilemmas and prospects for a peri-urban land use management framework: Evidence from Ethiopia. Land Use Policy 2021, 100, 105122. [CrossRef]

36. Tura, H.A. Land rights and land grabbing in Oromia, Ethiopia. Land Use Policy 2018, 70, 247-255. [CrossRef]

37. Biitir, S.B.; Nara, B.B.; Ameyaw, S. Integrating decentralised land administration systems with traditional land governance institutions in Ghana: Policy and praxis. Land Use Policy 2017, 68, 402-414. [CrossRef]

38. Agegnehu, S.K.; Mansberger, R. Community involvement and compensation money utilization in Ethiopia: Case studies from bahir dar and debre markos peri-urban areas. Sustainability 2020, 12, 4794. [CrossRef]

39. Dires, T.; Fentie, D.; Hunie, Y.; Nega, W.; Tenaw, M.; Agegnehu, S.K.; Mansberger, R. Assessing the Impacts of Expropriation and Compensation on Livelihood of Farmers: The Case of Peri-Urban Debre Markos, Ethiopia. Land 2021, 10, 614. [CrossRef]

40. Ferede, S.; Yirga, C.; Kehaliew, A.; Agegnehu, G.; Alemu, T. Farming Systems Characterization and Analysis in East Gojjam Zone: Implications for Research and Development (RED) Interventions; Ethiopian Institute of Agricultural Research: Addis Ababa, Ethiopia, 2020.

41. Motbainor, A.; Worku, A.; Kumie, A. Level and determinants of food insecurity in East and West Gojjam zones of Amhara Region, Ethiopia: A community based comparative cross-sectional study. BMC Public Health 2016, 16, 1-13. [CrossRef] [PubMed]

42. Teshome, T.; Ashebir, W. Best Practices on Development and Utilization of Acacia Decurrens in Fagta Lekoma District, Awi Zone, Amhara Region; Environment, Forest and Climate Change Commission: Addis Ababa, Ethiopia, 2019.

43. Yemane, M. Elemantary Sampling Theory; Printice-Hall Inc.: Englewood Cliffs, NJ, USA, 1967.

44. Council of Amhara National Regional State. The Revised Rural Land Administration and Use Determination Proclamation of the Amhara National Regional State; ZIKRE HIG: Bahir Dar, Ethiopia, 2017.

45. Bureau of Land Administration and Use. Directive No.1 of of Rural Land Administration; ZIKRE-HIG: Bahir Dar, Ethiopia, 2012. 
46. Council of the Amhara National Regional State. The Revised Amhara National Regional State Urban Land Lease Holding Regulation, Council of the Regional Government Regulation; ZIKRE-HIG: Bahir Dar, Ethiopia, 2012.

47. FDRE. Urban Lands Lease Holding Proclamation; Negarit Gazeta: Addis Ababa, Ethiopia, 2011.

48. Koroso, N.H.; Zevenbergen, J.A.; Lengoiboni, M. Land institutions' credibility: Analyzing the role of complementary institutions. Land Use Policy 2019, 81, 553-564. [CrossRef]

49. Agegnehu, S.K.; Fuchs, H.; Navratil, G.; Stokowski, P.; Vuolo, F.; Mansberger, R. Spatial urban expansion and land tenure security in Ethiopia: Case studies from Bahir Dar and Debre Markos peri-urban areas. Soc. Nat. Resour. 2016, 29, 311-328. [CrossRef]

50. UNECE. Land Administration Guidelines; United Nations Publication: New York, NY, USA; Geneva, Switzerland, 1996. 